Migraçōes Teóricas, Exercícios Literários 


\title{
Migrating LiteracieS redefining knowledge mobility for the digital age
}

\author{
LETRAMENTOS MIGRANTES: \\ REDEFININDO A MOBILIDADE DO CONHECIMENTO NA ERA DIGITAL
}

\author{
Diana Brydon* \\ University of Manitoba, Canada
}

\begin{abstract}
A B STRACT
This paper addresses several contexts of literary migration in the early twenty-first century that are changing how literary scholars read, the questions we pose, and the answers we find persuasive. How do ideas travel across time and space in the internet age? How does the literary engage the social, the political, the spatial and the temporal at a time of intensifying transworld connections? How are concepts of knowledge mobilization changing what we mean by the literary and how are globalizing processes changing what we mean by migration? What is the role of English in the circulation of ideas and the creation of literary value? Understanding literacy as the meaning-making practices in which readers engage, what kind of new literacies are required in our changing times? This paper adapts the concept of transnational literacies from the work of theorists such as Gayatri Spivak to engage current debates about the digital literacies of "digital natives," whose imaginative mobility is enabled by new media, and current literary interest in revalorizing mobility and reconsidering the material conditions that make it possible.
\end{abstract}

\section{KEYWORDS}

Literacy, Mobility, Knowledge

INTRODUCTION

Mobility and migration are defining themes of globalization. ${ }^{1}$ Literacy "has become a unifying term across a range of disciplines for changing views of reading and writing, and meaning-making more generally." ${ }^{2}$ When a shared concern for literacy operates

\footnotetext{
*Diana.Brydon@ad.umanitoba.ca

${ }^{1}$ BERLAND. Mobility.

${ }^{2}$ GRAFF. Literacy studies and interdisciplinary studies: reflections on history and theory, p. 274.
} 
across disciplinary and national borders, what literacy means also changes. The idea of literacy fragments into multiple literacies. The literacy required to engage with literature, one literacy among many, also changes, as Eurocentric imaginaries yield their hegemony to more reciprocal relations with those generated in other parts of the world. Ideas have always travelled ${ }^{3}$ but the rise of global English and the availability of new digital platforms are enabling the rapid circulation of ideas at a pace not previously experienced. These new mobilities are changing how literary critics read, the questions we pose, and the answers we find persuasive. How do ideas travel across time and space in the internet age? How does the literary engage the social, the political, the spatial, and the temporal, at a time of intensifying transworld connections? What kinds of new literacies are required to make sense of these engagements? How are concepts of knowledge mobilization changing the ways in which we understand the role of literary creators and critics and the work they do? What is the role of English in the transnational circulation of ideas and the creation of literary value?

This paper begins to engage such questions. With colleagues in Canada and Brazil, I have been funded by a Social Sciences and Humanities Research Council of Canada Partnership Development grant to encourage and intensify knowledge co-creation and mobilization between teachers in Canada and Brazil, working together to develop what we are calling "transnational literacies." ${ }^{4}$ We use this term to designate the challenge of making meanings within transnational circuits of exchange. One sign of our times is the proliferation of literacies now seen to be necessary to deal with contemporary life. For our purposes, the concept of "transnational literacies" operates as an umbrella term that privileges attention to the movements across and within the national contexts in which meanings are made. We do not see this as an exclusive approach but as an important one for our times. This paper explores the value of this approach for understanding knowledge mobilization through a two-part structure. First, I employ "transnational literacies" as an interpretive lens for understanding mobile imaginaries and considering the persuasiveness of some of the educational narratives embracing the capacity of digital platforms to change knowledge mobilization from models of transmission to models of interaction and co-production. Secondly, I consider how metaphorical understandings of how mobilities operate are changing; and some of the implications of these changes for understanding reading, writing, and making meaning now.

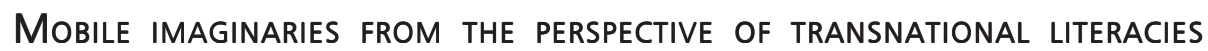

Mobile imaginaries have driven engagements with globalization within the human sciences since at least the 1990s. Scholars rely on metaphors of movement to describe

\footnotetext{
${ }^{3}$ SAID. Travelling theory; STOLOW. Wired religion: spiritualism and telegraphic globalization in the nineteenth century.

${ }^{4}$ The research for this paper was funded in part by the Canada Research Chairs program and the Social Sciences and Humanities Research Council of Canada Partnership Development Program. I am also grateful to Dr. Sandra Goulart Almeida for the invitation to deliver an earlier version of this paper at the conference on "Literary Migrations" at the Federal University of Minas Gerais in 2011.
} 
how globalization operates. Literature has always migrated across linguistic and political boundaries but for the last century, it has usually been studied either within such recognized borders, as a national literature, or across them, within comparative literature. Those formations for study are now being questioned. Most of us now understand globalization as involving patterns of disjunctive flows and sometimes unpredictable blockages that mark a world in which everything from finance to the earth's environment is interconnected. People are on the move, many physically, and many more imaginatively. Many of us are now connected through various forms of new technology, from the internet to the cell phone. New media enable people to be mobile without necessarily moving. There is talk of "convergence culture", 5 in which older forms of textual expression coexist and interact with the digital. Digital platforms offer new ways of writing and reading stories, which create new patterns of convergence across modalities and new routes for imaginative discoveries. Our times seem to be characterized by rapid changes in the ways we live, learn, and communicate. Those who resist change are often disparaged. In a highly competitive economy, it seems obvious the immobile will be left behind. In such a world, we are told that people need to learn to embrace change, and educational institutions need to change how they help prepare people for this world, or risk becoming redundant themselves.

I believe universities and schools do need to change but I also think we need to question some of the assumptions behind such calls for change. In particular, I am not convinced that some of the changes proposed are either as progressive or as radical as some of their proponents suggest. This paper raises some questions about the advantages and drawbacks of this new rhetoric of praise for mobile imaginaries, particularly those associated with migrations from the classroom to the internet and from text-based forms of reading to multimodal participations in digital environments. My approach draws on a postcolonial sensitivity to the legacies of colonialism and a concern for the ideological work that any popular rhetoric performs.

Our Brazil/Canada partnership project considers how Gayatri Chakravorty Spivak's theorization of "transnational literacy" can be adapted to enable learning for democratic participation in our changing times. ${ }^{6}$ Spivak's linking of deep language learning with geopolitical engagement, framed within an ethic of care for others and for the wellbeing of the planet, provides a basis for our understanding of what "transnational literacies" might involve. We pluralize the concept of literacy to indicate our distance from ethnocentric imperialist notions of literacy that were incapable of recognizing or respecting alternative modes of making meaning and to indicate our acknowledgement that the multimodality enabled by new technologies is changing how we understand the experience of reading, whether for pleasure or research. From that basis, we see a need to develop a range of literacy practices appropriate to the needs of different localities within Canada and Brazil. We are interested in how meaning-making practices change

\footnotetext{
${ }^{5}$ JENKINS. Convergence culture: where old and new media collide; JENKINS et al. Confronting the challenges of participatory culture: media education for the 21st century.

${ }^{6}$ SPIVAK. A critique of postcolonial reason: toward a history of the vanishing present, p. 357-399; SPIVAK. Death of a discipline, p. 81.
} 
within different contexts of production, reception, and circulation, and we are interested in the differences that teachers can make within the public schools and public universities we have.

Each of us has our own concerns within the project. Here are some of the questions I am asking within our team approach. How can students and teachers negotiate meanings in ways that truly enhance our autonomy, understood as our capacity to direct our lives as social beings? How can we distinguish between the uses to which physical and imaginative mobilities are put, and between various types of cognitive mobility now associated with educational innovations? What kinds of cognitive mobility might best serve the needs of cognitive justice? What are the roles for linguistic and literary study in such a venture?

By choosing "transnational literacies" as our overarching framework, we mean to imply that digital literacy cannot stand outside linguistic, sociopolitical, or geopolitical frames. Literacy is a social skill that requires negotiation across differences. Our partnership recognizes the continuing importance of the nation-state and its sub-regional provinces, states, and cities, particularly for the institutional frames in which educational systems operate, but we also believe these scales need to be placed within broader hemispheric and global frames. Ours is an experimental project in which we understand there are no established templates for what we hope to discover. Each of us within the project has our own views and we do not always agree, but we share a broadly-based commitment to a critical literacy approach.

Because of my involvement in other team projects working on "Globalization and Autonomy" and "Building Global Democracy," I am especially interested in the role education can play in enabling democratic engagement, both within and across national borders. Many writers see potential in the shifting forms of engagement enabled by new technologies. Our team sees digital and media literacies as essential components of the "transnational literacies" that need to be developed. However, I remain skeptical of some of the claims made for the transformative power of informal learning enabled by digital engagements alone. They allow new kinds of imaginative mobility and mobilization but are they truly creating a new kind of learning culture that can replace the kind of work that university teachers perform within our literature and language classrooms and research partnerships, as some claim?

The excitement, challenge, and potential drawbacks of new ways of thinking about knowledge mobilization are well exemplified in Douglas Thomas and John Seely Brown's book, A New Culture of Learning: Cultivating the Imagination for a World of Constant Change (2011). The book has received glowing reviews. I endorse some of their premises. But given the uncritical reception to date, I will focus here on introducing some cautionary notes. The book is openly nationalist, concerned with how the United States can regain its leading edge in the world, but in such a way as to suggest that the U.S. remains the trendsetter for the world, and that what applies there, will also apply elsewhere. The

\footnotetext{
${ }^{7}$ The author is grateful to the Social Sciences and Humanities Research Council of Canada for funding the Major Collaborative Research Initiative on "Globalization and Autonomy," and to the Ford Foundation for partial funding for the "Building Global Democracy" Program. Work with these interdisciplinary teams has been crucial to my thinking and the ideas I raise in this paper.
} 
authors find salvation in commercial applications of new digital technologies, especially their capacity to make learning fun, find information quickly, and encourage interaction and collaboration. Potentially, these are all valuable actions. However, as articulated in this text, these actions tend to become ends in themselves. The goal of interaction, for example, often seems to be interaction in itself, rather than collaboration in the production of knowledge. When there is a larger goal, it often seems to be finding information that is already available or meeting a goal set by the manufacturers of the game being played. I would have liked to see more attention paid to the limitations built in to these solutions as they currently operate.

Furthermore, to make their point, these authors stereotype current forms of learning as essentially passive while overestimating both the newness and the agency afforded by internet learning collectivities. In their view, the mobile human imagination will be liberated to innovate by the kind of collaborative play enabled by digital games or wikis, devising new solutions to challenges as they emerge, but always within the limits of capitalist expansion that has given us our "world of constant change." The imagination, as they understand it, does not extend to imagining alternatives to the current world order or even such dystopian consequences as imagined by Margaret Atwood in her novels, Oryx and Crake and The Year of the Flood. Instead, Thomas and Seely Brown celebrate the imaginative mobility afforded by digital platforms without considering their limitations.

They claim that "[a] growing digital networked infrastructure is amplifying our ability to access and use nearly unlimited resources and incredible instruments while connecting with one another at the same time". ${ }^{8}$ This environment enables forms of playbased learning that are almost invisible to learners and educational theorists alike, creating tacit forms of knowledge that may not be capable of full articulation, and thus requiring "a shift in our thinking about education". ${ }^{9}$ They have positive things to say about how internet-based collectivities enable people to learn together in ways those same people would object to when assigned group work in a classroom setting. The observation about motivation rings true, but the conclusions they draw from it fail to convince me.

Two of their anecdotes are particularly revealing. They compare a 2006 survey in which very few Americans could find Iraq on a map to their own student survey asking the same question with a computer. They claim that every student was able to find Iraq using Google and to employ it "as a new source of highly textured information". ${ }^{10}$ Yet their examples of such information retrieval are limited to technical proficiency in manipulating the views, from aerial to close-up. ${ }^{11}$ There seems to be no interest in learning about the culture or history of Iraq or about the causes and results of the illegal US

${ }^{8}$ THOMAS; BROWN. A new culture of learning: cultivating the imagination for a world of constant change, p. 17-18.

${ }^{9}$ THOMAS; BROWN. A new culture of learning: cultivating the imagination for a world of constant change, p. 18.

${ }^{10}$ THOMAS; BROWN. A new culture of learning: cultivating the imagination for a world of constant change, p. 92.

${ }^{11}$ THOMAS; BROWN. A new culture of learning: cultivating the imagination for a world of constant change, p. 92 . 
invasion. Thomas and Seely Brown praise the shift they see here from a learning focussed on "content" to learning that emerges from "process". I argue, however, that their excitement about process blinds them to the necessity for a continuing attention to analysis - and to the substance of content rather than merely its superficial contours. Process and content are not so easily separated without reducing process to mere technique.

Another moment raises further doubts. They revise a classic development narrative about the potential of education. The original saying runs as follows: "Give a man a fish and feed him for a day. Teach a man to fish, and feed him for a lifetime." They change the ending to read: "Teach a man to fish and feed him for as long as the fish supply holds out. But create a collective, and every man will learn how to feed himself for a lifetime." 12 Collective learning is valuable. But the context imagined for it here seems impoverished imaginatively because it seems to perpetuate dominant myths of progress. Perhaps it could be interpreted to mean that a collectivity would manage the fish supply responsibly, but given the dominant societal narrative of the "tragedy of the commons," and the resistance to collective decision-making expressed elsewhere in this text, it seems more likely this story assumes that humans' destruction of our environment will continue, but that collectively, we will be able to devise solutions to the destructions we cause after they have happened. Since fish do not recognize the boundaries set by collectives, to be effective, this imagined fisher collective would need to work on a global scale, yet at other points in their text, the authors resist taking collective interaction toward collective decisionmaking. In this way, the apparently utopian thrust of their book is undermined by the stories they tell. The supposedly "new culture of learning" they celebrate is less innovative than they claim because it accepts severe constraints on the scope of the human imagination to devise alternatives to the current order. Both stories associate learning with finding technical fixes to problems seen as discrete and unavoidable rather than reframing the problems themselves within larger contexts or seeking to change the contexts that have created the problems in the first place.

Like many digital enthusiasts, these authors praise games such as World of Warcraft for the teamwork they generate without questioning the imaginative poverty of the goals to which such teamwork is directed. These games are praised for substituting active participation for what the authors characterize as the passivity of more traditional teaching methods but the opposition is a false one. At its best, education can help students learn to set their goals for themselves and to question the goals that others set for them. Contrary to the claims that Thomas and Seely Brown make, I see a certain passivity at the heart of their project, which emerges in their contrasting of a community to a collective. In accordance with the privileging of mobility for its own sake that I am questioning throughout this paper, they see communities as primarily passive and collectives as active. But the activity they praise in a collective is participation for its own sake rather than consciously directed toward any particular end other than those set by the rules of the game in advance. Indeed, they explicitly rule out the kind of self awareness that critical literacy promotes, when they assert: "Blogs are a medium for

${ }^{12}$ THOMAS; BROWN. A new culture of learning: cultivating the imagination for a world of constant change, p. 53. 
learning, but they do not teach. Rather, they generate the space for a collective to emerge (...) Any effort to define or direct collectives would destroy the very thing that is unique and innovative about them." ${ }^{13}$ Yet surely the ability to determine a course of action is at the heart of human agency. If true change is to occur, then collectivities will need to find ways to direct themselves. That is what democracy is all about.

I dwell on this recent book at such length because these authors represent a dominant trend in current writing about educational innovation and because I share the value they place on collaborative learning and the need for educational reform while also finding certain dimensions of their argument alarming in their implications. In short, I fear that the kind of cognitive mobility they advocate serves to reproduce dominant norms even as it pretends to challenge them. In this respect, I agree with Gert Biesta when he concludes that "Nowadays there is too much talk about learning and too little talk about what learning is supposed to be for". ${ }^{14}$ Our Brazil/Canada Knowledge Exchange situates the question of what learning is for within a dialogue between Brazilian and Canadian educators because we believe we can best to begin to answer the question by sharing our experiences and learning from one another.

In an increasingly interconnected world, we think learning will need to involve developing greater hemispheric awareness and transworld understanding. As we learn more about each other, we may also find ourselves questioning some of the common sense of our times and our places, recognizing that many of the generalizations about ourselves and our world currently circulating as accepted truths have been developed out of a specific local context that has passed itself off as a universal. Formerly colonized cultures know what Kamau Brathwaite has called "the terrible terms meted out for [such] universality." 15 The internet affords space to challenge those terms but without critique people will be unlikely to encounter perspectives that interrupt what they think they already know. In failing to situate their argument explicitly within a particular local context, Thomas and Seely Brown assume that US-based experiences of the internet can stand in for the vanguard of a potentially more universal experience. Such an assumption requires questioning.

In accepting that literacies are "a plural set of practices", ${ }^{16}$ we need always to ask "what are the material or political consequences of different literacy practices?"17 Thomas and Seeley Brown assume that "hanging out, messing around, and geeking out," the modes of youth engagement identified by Ito and her colleagues as practised within the United States in the early twenty-first century, are uniformly valuable because they make self-directed learning enjoyable. ${ }^{18}$ They provide a motivation to learn that schools,

${ }^{13}$ THOMAS; BROWN. A new culture of learning: cultivating the imagination for a world of constant change, p. 53-54.

${ }^{14}$ BIESTA. Learning democracy in school and society: education, lifelong learning, and the politics of citizenship, p. 127.

${ }^{15}$ BRATHWAITE. History of the voice, p. 20.

${ }^{16}$ James Gee cited in PENNYCOOK. Global Englishes and transcultural flows, p. 119.

${ }^{17}$ PENNYCOOK. Global Englishes and transcultural flows, p. 120.

${ }^{18}$ ITO. Hanging out, messing around, and geeking out: kids living and learning with new media. 
as currently constituted, cannot replicate. However, they fail to investigate carefully enough what the point of such learning may be, beyond implying that learning to learn, as a lifelong, questing activity, is sufficient goal in itself, given that our rapidly changing world requires lifelong, continuous learning in all spheres of engagement. This is partially true, but learning how to learn is just a first step. Mobile imaginaries also need to be rooted in values that enable the appreciation of "difficult forms of learning," of interruptions that challenge our thinking, and even redefine our pleasures. They also require more attention to the institutional infrastructures underpinning these new forms of engagement.

These are some of the considerations that lead me to ask: what insights can a focus on literary migrations offer now? Is migration seen as the default norm of human activity or as an exceptional occurrence in a normally sedentary world? Is migration feared or welcomed, seen as renewing the nation or threatening its existence? Is literature seen as a closed autonomous system or a social practice constantly under construction?

\section{LITERARY MIGRATIONS}

Migration functions as a particularly interesting metaphor for the movement of people and ideas in the wake of the major European colonizations of the globe since Columbus journeyed to the Americas. Like diaspora, migration once described a particular type of movement, a scattering from a source outward toward a new host destination, that is, a linear movement from a set beginning to an end. With the rise of globalization, however, these terms are assuming new and more complex definitions that mirror disciplinary transitions away from what Ulrich Beck has termed "methodological nationalism" toward versions of the replacement frame he favours: that of "methodological cosmopolitanism." "Methodological nationalism" assumes that the nation-state is the logical frame for analysis and therefore functions as if the borders of the state form a natural limit between an outside and an inside. "Methodological cosmopolitanism" assumes that after the intensified globalizing trends of the last few decades, nation-state borders have becoming increasingly porous to such an extent that scholars must now take the entire globe, world, planet or cosmos as the frame within which we work. Neither of these terms is singular or simple. Their scope and value are disputed. Nonetheless, they are useful ways to understand some of what seems to be at stake in discussions of theoretical or literary migration today.

From the perspective of "methodological nationalism," taking the nation-state as the lens through which to view migration, people and ideas are seen to move from one bounded place to another. When the lens is switched to "methodological cosmopolitanism" 20 then the globe becomes the space through which people and ideas are seen to circulate. In this view, circulation or a series of movements replaces the

\footnotetext{
${ }^{19}$ BECK. The cosmopolitan vision.

${ }^{20}$ SCHILLER; DARIEVA; GRUNER-DOMIC. Defining cosmopolitan sociability in a transnational age. An introduction.
} 
single trajectory of the migrant who becomes a settler. This latter view is becoming more persuasive as social values move away from earlier suspicions of mobility toward approving and even demanding it in certain circumstances. Whereas colonization privileged the settler over the nomad, contemporary theory embraces nomadic over settled thought. Ideas of brain circulation replace talk of "brain gain" and "brain drain." Neither "methodological nationalism" nor "methodological cosmopolitanism" seems capable of capturing the full complexity of movements today nor can they describe the varied emotions different people feel about their own mobility or the mobility of others. Each lens shows a different aspect of contemporary movement with different implications for public policy and democratic practice. Is it possible to stand back from the advocates of these different approaches to think about mobility within a wider variety of theoretical contexts?

To think about that question, I turn to the ways in which contemporary definitions of mobility are changing and expanding. People have always moved; yet contemporary theorists see those movements as especially relevant to the concerns of today. Arjun Appadurai's Modernity at Large makes culture, modernity and mobility an especially important nexus for understanding global change. Here Appadurai explains that "[i]mplicit in this book is a theory of rupture that takes media and migration as its two major, and interconnected, diacritics and explores their joint effect on the work of the imagination as a constitutive feature of modern subjectivity". ${ }^{21}$ This is still largely the dynamic through which most thinking about globalization and culture works. Appadurai's book links the movements of peoples to new media in ways that seem to capture a moment of rupture from earlier paradigms. His outline of "five dimensions of global cultural flows that can be termed (a) ethnoscapes, (b) mediascapes, (c) technoscapes; (d) financescapes, and (e) ideoscapes", ${ }^{22}$ by now well known, provides a language for linking different dimensions of larger social movements. Flow describes movement through time and space. As Anna Lowenhaupt Tsing noted in Friction: flow does not happen without “'friction,' the grip of worldly encounter". ${ }^{23}$ She explains: "As a metaphorical image, friction reminds us that heterogeneous and unequal encounters can lead to new arrangements of culture and power." ${ }^{4}$ In her view, "Friction is not a synonym for resistance", ${ }^{25}$ but rather a way of insisting upon the interactions that define movement. Tsing draws attention to "movement as mobility and movement as mobilization"26 - a key element in all the definitions I have cited so far.

Tsing notes that " $[\mathrm{s}]$ cholars have had difficulty in imagining how to trace traveling forms of politics; the two most available models, national history and global circulation, territorialize and universalize, respectively, each erasing travel". ${ }^{27}$ Theories of the transnational bring these models together, potentially making the travelling nature of

\footnotetext{
${ }^{21}$ APPADURAI. Modernity at large: cultural dimensions of globalization, p. 3.

${ }^{22}$ APPADURAI. Modernity at large: cultural dimensions of globalization, p. 33.

${ }^{23}$ TSING. Friction: an ethnography of global connection, p. 1.

${ }^{24}$ TSING. Friction: an ethnography of global connection, p. 5.

25 TSING. Friction: an ethnography of global connection, p. 6.

${ }^{26}$ TSING. Friction: an ethnography of global connection, p. 214.

${ }^{27}$ TSING. Friction: an ethnography of global connection, p. 216.
} 
each more visible. But at least two questions remain. Firstly, the search for a resolving third term or space does not resolve the problem of the very way of thinking that makes binary oppositions, and their resolution through a third term, seem natural. Secondly, a simple focus on travel, or movement itself, begs the question of how that travel is understood and how it impacts the world around it.

On the first point, Tsing points out that the apparent opposition between particularity and universality is itself an imperialist construction of a certain point in time, and Nicholas Birns notes that substituting pluralities for binaries risks merely substituting new platitudes for the old. The task as he sees it is to go beyond certain "easy pluralities that different schools of theory hail as beneficial. For deconstruction it is difference; for feminism, desire; for race and ethnicity studies, mestizaje; for post-colonial studies, hybridity; for gender studies, a particular definition of the queer". ${ }^{28}$ Perhaps for literacy theorists, it is multiliteracies. These shifts seem mirrored in the turn to talk of multiple modernities, many globalizations, and contending postcolonialities. Such shifts away from master narratives may seem initially progressive but without further investigation, their promise can be illusory.

Nikos Papastergiadis suggests that despite a persistent anxiety about migration in contemporary discourse, questions about the nature and impact of mobility remain. He asks: "What is mobility - a state, a force, a set of shifting co-ordinates? How does the definition of mobility shape social attitudes and personal experiences?"29 In "Wars of Mobility," he argues that organic and mechanistic metaphors, which have shaped "the classical paradigm for understanding mobility in the social sciences" are not well suited for understanding contemporary movements. In place of Beck's "methodological nationalism," Papastergiadis writes of dominant "residentialism" and "kinetophobia" within the paradigms employed for studying migrant movement. This means that global statistics are hard to compile and that "[d] espite the promotion of arguments by [various global agencies] that migration is a global issue, there is still no single regulative authority" to oversee such movements or to enforce the conventions to which states are signatories. ${ }^{30}$ This is the kind of problem that the team project "Building Global Democracy," in which I participate, is designed to address.

Papastergiadis approvingly cites John Urry's call "for a new mobility paradigm" 31 suited to the mobility patterns emerging with globalization, which could enable better appreciation of the ways in which migration is "a dynamic and constitutive feature of social life". ${ }^{32}$ Such a revised paradigm also holds potential for developing "a new conceptual understanding of the interplay between mobility and belonging", 33 a need our "Globalization and Autonomy" team began to explore in our series with the University

\footnotetext{
${ }^{28}$ BIRNS. Theory after theory: an intellectual history of literary theory from 1950 to the early twentyfirst century, p. 317.

${ }^{29}$ PAPASTERGIADIS. Wars of mobility, p. 343.

${ }^{30}$ PAPASTERGIADIS. Wars of mobility, p. 352.

${ }^{31}$ PAPASTERGIADIS. Wars of mobility, p. 353.

${ }^{32}$ PAPASTERGIADIS. Wars of mobility, p. 254.

${ }^{33}$ PAPASTERGIADIS. Wars of mobility, p. 353.
} 
of British Columbia Press. Papastergiadis turns to complexity theory for "a new way of thinking about identity and motion," a way of thinking that sees "movement as an intrinsic part of belonging, and vice versa". ${ }^{34} \mathrm{He}$ concludes his essay by suggesting, "[i]f we were to re-imagine society as a complex system, then it is possible that the social status of mobility would go beyond the kinetophobic associations". ${ }^{35}$ In this paper, I am interested in the implications of his argument for literary studies.

I have suggested that the social status of mobility has already moved beyond anxiety toward celebration in many dimensions of social, business and academic life. State policy, however, remains an area where kinetophobia still reigns. Language is another area where anxiety about migration remains. Alastair Pennycook ${ }^{36}$ writes:

I use the term global Englishes to locate the spread and use of English within critical theories of globalization. English is closely tied to processes of globalization: a language of threat, desire, destruction and opportunity. It cannot be usefully understood in modernist states-centric models of imperialism or world Englishes, or in terms of traditional, segregationist models of language. ${ }^{37}$

He explains that "By taking up metaphors of movement and the spatial frames of 'trans' theories (...), I am trying here to escape from the debates over globalization versus localization". ${ }^{38}$ He lists the tasks that studies of global English need to take on:

we need to understand how English is involved in global flows of culture and knowledge, how English is used and appropriated by users of English around the world, how English colludes with multiple domains of globalization, from popular culture to unpopular politics, from international capital to local transaction, from ostensible diplomacy to purported peace-keeping, from religious proselytizing to secular resistance. ${ }^{39}$

Like Beck, he wants to move beyond frameworks that replicate "methodological nationalism," arguing that "[j] ust as we need to think outside the notion of the nationstate, so too we need to rethink language". 40

For Pennycook, languages "cannot be treated as autonomous systems outside the other meaning-making practices of the bodies, texts, contexts and histories in which they are embedded". ${ }^{41}$ Therefore, he "prefers the terms transmodality to multimodality, since it implies that meaning occurs across modes of meaning-making that transgress established beliefs in discrete channels". ${ }^{42}$ I wonder if this shift in terminology implies that Alan Liu's modeling of transliteracies might prove more productive than thinking in terms of

\footnotetext{
${ }^{34}$ PAPASTERGIADIS. Wars of mobility, p. 355.

${ }^{35}$ PAPASTERGIADIS. Wars of mobility, p. 357.

${ }^{36}$ PENNYCOOK. Global Englishes and transcultural flows.

${ }^{37}$ PENNYCOOK. Global Englishes and transcultural flows, p. 5.

${ }^{38}$ PENNYCOOK. Global Englishes and transcultural flows, p. 7.

${ }^{39}$ PENNYCOOK. Global Englishes and transcultural flows, p. 19.

${ }^{40}$ PENNYCOOK. Global Englishes and transcultural flows, p. 27.

${ }^{41}$ PENNYCOOK. Global Englishes and transcultural flows, p. 49.

${ }^{42}$ PENNYCOOK. Global Englishes and transcultural flows, p. 49.
} 
multiliteracies. Such a move recognizes Birns's point that simply pluralizing a concept does not address its fundamental difficulties. Yet, to put too much weight on the "trans" might also merely deflect questions we ought to be confronting head-on. Within interdisciplinary studies, for example, Julie Thompson Klein identifies an "interdisciplinary spectrum" in which the "transdisciplinary" represents the model closest to "full integration" and "restructuring". ${ }^{43}$ Klein notes of "transciplinarity" that "[t]he escalation of this keyword signals a new phase in the history of the keyword 'interdisciplinarity". ${ }^{44}$ That new phase, as always, will be need to be evaluated in relation to the goals of the particular projects involved. "Transdisciplinarity" will not be a solution in every case.

Pennycook's arguments are powerful incentives for thinking of "culture as travel rather than place" 45 and for focusing on what happens within the contact zones that are all around us. I find this thinking persuasive. Yet what gets blocked when we concentrate on the flow? I can think of at least two immediate answers. First of all, in Canada, where treaties with indigenous peoples have still not been fully implemented or acknowledged, a focus on mobility as the norm can obscure acknowledgement of native land rights. To say, with Atwood, that "we are all immigrants to this place" 46 is to blur the different relations to movement and to place experienced and claimed by different groups and to downplay the claims of the First Peoples. In this Canadian context, Malissa Phung, the child of immigrants, asks the now somewhat neglected question: "what exactly does being a settler mean?" 47 Secondly, as a recent special issue of PMLA asks, what are the energy sources that power our current fascination with movement? Can a celebration of mobility obscure the material relations that fuel it?

PMLA is one of two special journal issues that have taken literary mobility as a question for our times by adopting different lenses for linking literary study to material realities organized around mobility. "Jamming - theTraffic issue" of English Studies in Canada (2010) investigates the metaphor of traffic that links everyday movements from place to place to more illicit forms of movement across borders. Cecily Devereux and Mark Simpson, the editors, ask: "Why 'traffic' now?"48 and "How do English studies engage with traffic?" 49 They conclude that

critical reflection, stalling and blocking dominant modes of traffic, can carve out all sorts of new passageways. At stake is the unforeseen exchange, the unimagined circuit, the incipient process. The turn toward traffic admits all these possibilities and more; it enables as it demands nothing less than the remobilization of culture. ${ }^{50}$

\footnotetext{
${ }^{43}$ KLEIN. Interdisciplinarity, Humanities, and the terministic screens of definition, p. 151.

${ }^{44}$ KLEIN. Interdisciplinarity, Humanities, and the terministic screens of definition, p. 159.

${ }^{45}$ PENNYCOOK. Global Englishes and transcultural flows, p. 156.

${ }^{46}$ ATWOOD. The journals of Susannah Moodie.

${ }^{47}$ PLUNG. Are people of colour settlers too?, p. 292.

${ }^{48}$ DEVEREUX; SIMPSON. Jamming - the traffic issue, p. 3.

${ }^{49}$ DEVEREUX; SIMPSON. Jamming - The traffic Issue, p. 5.

${ }^{50}$ DEVEREUX; SIMPSON. Jamming - The traffic Issue, p. 13.
} 
The Editor's Colum in PMLA (2011) suggests a remobilization that turns away from dividing literary works "into hundred-year intervals...or categories," in favour of asking "what happens if we sort texts according to the energy sources that made them possible?" 51 Patricia Yaeger charts "some coordinates for an energy-driven literary theory", 52 suggesting that "thinking about literature through the lens of energy, especially the fuel basis of economies, means getting serious about modes of production as a force field for culture". ${ }^{53}$ Such an approach, she argues, could change "reading methodologies," compelling attention to a text's "energy unconscious" along the lines of Fredric Jameson's theorization of the "political unconscious" 54 and enabling contemplations of literature in relation to scale and trade. ${ }^{55}$

Imre Szeman, in responding to Yeager's Editor's Column, restates the Forum's theme as reframing literature away from "movements (e.g., modernism), nations (British modernism), or centuries" toward placing it "in relation to dominant forms of energy" ${ }^{56}$ To this extent, this special issue merely continues the contemporary fascination with mobility by taking it one step further. But what Szeman finds when looking for acknowledgment of the reliance of the contemporary world on oil is "the almost complete absence of oil as subject matter (direct or allegorical) in the literature written during the era when it is dominant". ${ }^{57}$ He concludes in disappointment that "instead of challenging the fiction of surplus - as we might have hoped or expected - literature participates in it just as surely as every other social narrative in the contemporary era". ${ }^{58}$ My argument in this paper has shown the ways in which certain educational narratives celebrating the mobile digital literacy of "digital natives" also reinforce such fictions of surplus, but through reliance on human ingenuity rather than oil, and I have also found contemporary social narratives, in literature and in criticism, that offer different models for thinking about cognitive mobility in the service of cognitive justice, models Spivak cautiously aligns with the emergent theorizing of "transnational literacies."

"Transnational literacies" names an imaginative effort toward imagining forms of meaning-making that reconfigure relations between local and global without privileging either scale or those in between. Those articulating "transnational literacies" can work with the digital but remain wary of both technicist and utopian imaginaries that neglect the power relations that continue to structure the currently separated, but increasingly

\footnotetext{
${ }^{51}$ YAEGER. Editor's column: literature in the ages of wood, tallow, coal, whale oil, gasoline, atomic power, and other energy sources, p. 305.

${ }^{52}$ YAEGER. Editor's column: literature in the ages of wood, tallow, coal, whale oil, gasoline, atomic power, and other energy sources, p. 307.

${ }^{53}$ YAEGER. Editor's column: literature in the ages of wood, tallow, coal, whale oil, gasoline, atomic power, and other energy sources, p. 308.

${ }^{54}$ YAEGER. Editor's column: literature in the ages of wood, tallow, coal, whale oil, gasoline, atomic power, and other energy sources, p. 309.

${ }^{55}$ YAEGER. Editor's column: literature in the ages of wood, tallow, coal, whale oil, gasoline, atomic power, and other energy sources, p. 310.

${ }^{56}$ SZEMAN. Literature and energy futures, p. 323.

${ }^{57}$ SZEMAN. Literature and energy futures, p. 324.

${ }^{58}$ SZEMAN. Literature and energy futures, p. 324.
} 
blurred, worlds of education and play. This essay marks a preliminary effort to bring together thinking clustered around changing ideas about mobility, literacies, and the transnational. These powerfully emotive concepts are functioning to redirect thinking about learning, understanding, and belonging in ways that require further analysis.

\section{RESU MO}

Este trabalho discute vários contextos de migrações literárias do início do século 21 que estão mudando a forma como lemos textos literários, os questionamentos que fazemos e as perguntas que julgamos relevantes. Como as ideias viajam através do tempo e espaço na era digital? Como o literário se engaja em questões sociais, políticas, de tempo e de espaço em uma era de conexões transnacionais intensas? Como os conceitos de mobilidade de conhecimento estão mudando o que chamamos de literário e como os processos de globalização estão mudando o que chamamos de migração? Qual o papel do inglês na circulação de ideias e na criação de valor literário? Considerando o letramento como uma prática de construção de significados com a qual leitores se engajam, que tipo de novos letramentos são necessários em nossa era de intensas mudanças? Este trabalho adapta o conceito de letramentos transnacionais de teóricos como Gayatri Spivak com o objetivo de discutir debates atuais sobre os letramentos digitais daqueles sujeitos considerados "nativos digitais", cuja mobilidade imaginativa é proporcionada pelas novas mídias, e o interesse atual da literatura em valorizar a mobilidade e reconsiderar as condições materiais que permitem tal valorização.

PALAVRAS - CHAVE

Letramento, mobilidade, conhecimento

\section{WORKS CITED}

APPADURAI, Arjun. Modernity at large: cultural dimensions of globalization. Minneapolis: University of Minnesota Press, 1996.

ATWOOD, Margaret. The journals of Susannah Moodie. Toronto: Oxford University Press, 1970.

ATWOOD, Margaret. Oryx and crake. Toronto: McClelland and Stewart, 2003.

ATWOOD, Margaret. The year of the flood. Toronto: Random House Canada, 2009.

BECK, Ulrich. The cosmopolitan vision. Trans. Ciaran Cronin. London: Polity, 2006.

BERLAND, Jody. Mobility. In: BENNETT Tony; GROSSBERG Lawrence; MORRIS Meaghan (Ed.). New keywords: a revised vocabulary of culture and Society. Malden \& Oxford: Blackwell, 2005. p. 217-219.

BIESTA, Gert J. J. Learning democracy in school and society: education, lifelong learning, and the politics of citizenship. Rotterdam: Sense Publishers, 2011. 
BIRNS, Nicholas. Theory after theory: an intellectual history of literary theory from 1950 to the early twenty-first century. Peterborough: Broadview, 2010.

BRATHWAITE, E.K. History of the voice. London: New Beacon, 1984.

BUILDING Global democracy website. Available on: < http://www.buildingglobal democracy.org >. Accessed on: 1 Mar. 2012.

COLEMAN, William D.; SZEMAN, Imre; RETHMANN, Petra. Introduction: cultural autonomy, politics, and global capitalism. In: Petra RETHMANN, Imre; SZEMAN; William D.; COLEMAN (Ed.) Cultural autonomy: friction and connections. Vancouver: University of British Columbia Press, 2010. p. 1-27.

DEVEREUX, Cecily; SIMPSON, Mark. Jamming - the traffic issue. English Studies in Canada, v. 36, n. 1, p. 1-14, 2010.

GLOBALIZATION and autonomy compendium. Available at: < http://globalautonomy. ca/global1/news.jsp>. Accessed on: 1 Mar. 2012.

GOlDBERG, David Theo. Praise the Web. PMLA, v. 126, n. 2, p. 448-54, 2011.

GRAFF, Harvey. Literacy studies and interdisciplinary studies: reflections on history and theory. In: FOSHAY, Raphael (Ed.). Valences of interdisciplinarity. Edmonton: University of Athabaska Press, 2012. p. 273-307.

HARVEY, David. The condition of postmodernity: an enquiry into the origins of cultural change. Cambridge, MA: Blackwell, 1990.

ITO, Mizuko et al. Hanging Out, Messing Around and Geeking Out: Kids Living and Learning with New Media. Boston, Mass.: MIT Press, 2009.

JENKINS, Henry. Convergence culture: where old and new media collide. New York/ London: New York University Press, 2006.

JENKINS, Henry et al. Confronting the challenges of participatory culture: media education for the $21^{\text {st }}$ century. Cambridge, Mass./London: MIT Press, 2009.

KLEIN, Julie Thompson. Interdisciplinarity, humanities, and the terministic screens of definition. In: FOSHAY, Raphael (Ed.). Valences of interdisciplinarity. Edmonton: University of Athabaska Press, 2012. p. 137-164.

MOONEY, Annebelle; EVANS, Betsy. Migration. In: . (Ed.). Globalization: the key concepts. London: Routledge, 2007. p. 166.

MOONEY, Annabelle; EVANS, Betsy. Mobility. In: . (Ed.). Globalization: the key concepts. London: Routledge, 2007. p. 166-167.

PAPASTERGIADIS, Nikos. Wars of mobility. European Journal of Social Theory, v. 13, n. 3, p. 343-361, 2010.

PENNYCOOK, Alastair. Global Englishes and transcultural flows. London/New York: Routledge, 2007.

PHUNG, Malissa. Are people of colour settlers too? In: MATHUR, Ashok; DEWAR, Jonathan; DEGAGNE, Mike (Ed.). Cultivating Canada: reconciliation through the lens of cultural diversity. Ottawa: Aboriginal Healing Foundation Research Series, 2011. p. 291-298.

SAID, Edward. Traveling theory. In: . The world, the text and the critic. Cambridge, Massachusetts: Harvard University Press, 1983. p. 157-181. 
SIEMERLING, Winfried; CASTEEL, Sarah Phillips (Ed.). Canada and its Americas: transnational navigations. Montreal/Kingston: McGill-Queen's University Press, 2010. SCHILLER, Nina Glick; TSYPYLMA Darieva; GRUNER-DOMIC, Sandra (Ed.). Defining cosmopolitan sociability in a transnational age: an introduction. Ethnic and Racial Studies, v. 34, n. 3, p. 399-418, 2011.

SPIVAK, Gayatri Chakravorty. A critique of postcolonial reason: toward a history of the vanishing present. Cambridge, Mass.: Harvard University Press, 1999.

SPIVAK, Gayatri Chakravorty. Death of a discipline. New York: Columbia University Press, 2003.

STOLOW, Jeremy. Wired religion: spiritualism and telegraphic globalization in the nineteenth century. In: STREETER, S. M.; J. C. WEAVER; COLEMAN, W. D. (Ed.). Empires and autonomy: moments in the history of globalization. Vancouver: University of British Columbia Press, 2009. p. 79-92.

SZEMAN, Imre. Neoliberals dressed in black; or, the traffic in creativity. ESC, v. 36, n. 1, p. 15-36, 2010.

SZEMAN, Imre. Literature and energy futures. PMLA, v. 126, n. 2, p. 323-25, 2011.

THOMAS, Douglas; BROWN, John Seely (Ed.). A new culture of learning: cultivating the imagination for a world of constant change. [S.1]: CreateSpace, 2011.

TSING, Anna Lowenhaupt. Friction: an ethnography of global connection. Princeton: Princeton University Press, 2005.

YAEGER, Patricia. Editor's column: literature in the ages of wood, tallow, coal, whale oil, gasoline, atomic power, and other energy sources. PMLA, v. 126, n. 2, p. 305-10, 2011. 